\title{
MENINGKATKAN SIKAP EMPATI MELALUI METODE MENDONGENG PADA ANAK USIA DINI
}

\author{
Wiwin Winangsih ${ }^{1}$, Lastri Yuniarti ${ }^{2,}$ Ema Apriyanti ${ }^{3}$ \\ ${ }^{1}$ TK Bustanul Arifin Bandung Barat' \\ 2 TK BustanulArifin Bandung Barat \\ ${ }^{3,}$ IKIP Siliwangi \\ wiwinwinangsih0108@gmail.com ${ }^{1}$, lastriyuniarti367@gmail.com² \\ emaaprianti88@gmail.com ${ }^{3}$
}

\begin{abstract}
Empathy is the ability of someone to put themselves in the position of others, to understand the views and feelings of people or to experience what the person experienced. Storytelling method is a way of delivering the learning done orally and by engineered by the storyteller of movement and body expression, the fairy tale has a specific meaning that is something related to the world of fantasy.the empathy ability of children of A group Bustanul Arifin Kindergarten is still low. The purpose of this study is to obtain an overview of the improvement of empathy ability of children through the application of storytelling method. The research was done by research method of class action of this research data collected through observation and documentation of data which have been collected analyzed by description.In accordance with the results of the research we have analyzed and it can be concluded that the development of empathy of Group A children from the number of children 25 consisting of 12 males and 13 girls in fact has increased, this is derived from the final result after the implementation of the action on cycle 2 which can be explained from each number of children in the category of $\mathrm{BB}$ as many as 3 children, in the MB category, as many as 7 children, in the category of $\mathrm{BSH}$, as many as 11 children, and on BB category, a number of 4 children.
\end{abstract}

Keyword: emphaty and storytelling method

\begin{abstract}
Abstrak
Empati merupakan kemampuan sesorang untuk menempatkan diri pada posisi orang lain, untuk mengerti pandangan dan perasaan orang atau untuk mengalami seperti apa yang dialami orang tersebut. Metode mendongeng merupakan cara penyampaian pembelajaran yang dilakukan secara lisan dan dengan direkayasa oleh pendongeng dari gerakan maupun ekspresi tubuh, dongeng memiliki makna yang spesifik yaitu sesuatu yang berkaitan dengan dunia khayalan. Kemampuan empati anak kelompok A TK Bustanul Arifin masih rendah. Tujuan penelitian ini untuk memperoleh gambaran mengenai peningkatan kemampuan empati anak melalui penerapan metode mendongeng. Penelitian dilakukan dengan metode penelitian tindakan kelas data penelitian ini dikumpulkan melalui observasi dan dokumentasi data yang sudah terkumpul dianalisis secara deskripsi. Seiring
\end{abstract}


dengan dilaksanakan nya penelitian, kami dapat menyimpulkan hasil bahwa perkembangan empati anak Kelompok A dari jumlah anak 25 yang terdiri dari 12 laki-laki dan 13 anak perempuan pada kenyataan nya mengalami peningkatan, hal ini diambil dari hasil akhir setelah pelaksanaan tindakan pada siklus 2 yang mana bisa jelaskan dari masing-masing jumlah anak yang berada pada kategori BB sebanyak 3 orang anak, pada kategori MB, sebanyak 7 orang anak, pada kategori $\mathrm{BSH}$, sebanyak 11 orang anak, dan pada karegori BB, sejumlah 4 orang anak.

Kata kunci: empati dan metode mendongeng

\section{Pendahuluan}

Penanaman pendidikan yaitu bagian untuk menentukan keberhasilan suatu bangsa dengan membangunnya para generasi-generasi bangsa yang mana bisa mengisi memperjuangkan maupun menjaga nama bangsa beserta isinya dengan sikap generasi yang bermoral dan beretika, karena dengan pendidikan merupakan cara mengasuh, membimbing maupun menerapkan yang tujuannya membentuk kepribadian seseorang sesuai dengan harkat martabat, dan moral yang ditetapkan, oleh suatu bangsa. Untuk itu pentingnya penanaman pendidikanpada anak-anak, sebagai calon pengisi bangsa, upaya untuk mencerdaskan suatu bangsa melalui pendidikan dengan mencakup pengetahuan, keterampilan. seperti yang tercantum dalam Undang-Undang Repulblik Indonesia No 20 Tahun 2003 tentang Sistem Pendidikan Nasional Bab II Pasal 3, yang isinya yaitu Pendidikan nasional berfungsi mengembangkan kemampuan dan membentuk watak serta peradaban bangsa yang bermartabat dalam ranka mencerdaskan kehidupan bangsa dengan sasaran mengembangkan potensi peserta didik agar menjadi manusia yang beriman dan bertaqwa kepada Tuhan Yang Maha Esa, berakhlak mulia, serta berilmu, sehat, kreatif, mandiri dan menjadi warga yang demokratis serta bertanggung jawab.Sikap empati pada seseorang sangatlah menentukan sikap seseorang ketika bersosialisasi atau pun bergaul dalam kehidupannya sehari-hari, dengan sebagaimana mestinya disebutkan bahwa manusia itu sebagai mahluk yang hidup bermasyarakat atau pun makhluk yang hidup sling bergantungan satu sama lainnya, sedini mungkin ditanamkan sikap positip maka merupakan suatu bekal yang sangat berguna intuk kehidupan anak sampai nanti kelak, dan dengan mempunyai sikap empati cukup tinggi, maka akan mempunyai etika yang diharapkan pula dalam masyarakat.Pendidikan dimasa pra sekolah merupakan pendidikan yang ditanamkan untuk anak dari umur 0-6 tahun yang mana pada masa itu di sebut dengan golden ageyang artinya masa keemasan maksudnya pada masa tersebut, sesuatu hal yang diterapkan baik itu sikap nya positip atau negatip sehingga akan senantias menjadi pembiasaan anakseterusnya.Pendidikan berpengaruh dalam mengembangkan seluruh aspek perkembangan antara lain: aspek perkembangan agama dan moral, sosial emosional, kognitif, bahasa, fisik motorik, dan seni. Seluruh aspek tersebut perlu dikembangkan sejak dini, khususnya disini yaitu aspek sosial emosional yang mana berhubungan dengan bagaimana sikap atau prilaku anak yang semestinya diterapkandi lingkungan kehidupan sehari-hari. Karena anak baru mengenal dunia, belum 
mengenal aturan cara bersosialisasi atau pun bersikap pada orang lain.

Empati merupakan suatu emosi pada anak yang mampu melihat kesusahan orang lain. untuk mengerti pandangan dan apa yang seseorang rasakan. Walaupun sikap empati sudah ada pada anak namun harus lebih diterapkan supaya tertanampada diri anak agar kelak anak dapat berada di lingkungan sosial bergaul dengan teman atau siapapun akan tertanam prilaku baik dan saling menolong agar anak dapat diterima di lingkungan baik itu lingkungan sekolah atau pun lingkungan masyarakat. Menurut Gardner dalam buku yang berjudul Memahami Permasalahan Anak Usia Dini (2017: 31), menyebutkan bahwa keterampilan inti yang perlu dimiliki anak agar memiliki kualitas hubungan sosial yang bagus, yaitu memahami diri, memahami orang lain, dan melakukan peran sosial. yaitu sikap empati tersebut, karena dengan seseorang ditanamkan atau ditumbuh kembangkan sikap empatinya yaitu sebagai kunci untuk kehidupan bersosialisasi dan bisa beradaptasi seperti anak bisa mencerminkan perasaan toleransi pada temannya mencerminkan rasa kasih sayang, mengerti kebutuhan temannya serta mau menolong teman yang mengalami kesulitan, anak akan mampu mengendalikan emosinya seperti ketika melakukan kesalahan, mau meminta maaf, mau bermain bersama dan saling berbagi.

Melihat semua yang dipaparkan tersebut tentang sikap empati yang mesti diterapkan atau ditumbuh kembangkan sejak dini pada anak, pada kenyataannya sangat berbeda dengan yang peneliti temukan. hal tersebut bisa saya lihat waktu observasi yaitu permasalahan yang masih sangat menonjol yaitu adanya sikap anak yang belum berkembang dilihat dari sikap empatinya dari kebiasaan anak sehari-hari di sekolah seperti anak masih suka berbuat jail terhadap teman, pilih-pilih dalam berteman, mengejek teman, mudah terbawa emosi selalu berebut mainan, dan kurangnya rasa berbagi, Hal ini terjadi mungkin penyebab utamanya yaitu kurangnya guru bisa menerapkan pendidikan khususnya untuk meningkatkan sikap empati anak, saya perhatikan, dalam menghadapi hal tersebut yang guru lakukan hanya melarang anak, untuk berbuat seperti itu, memberi nasehat dengan cara bicara langsung terhadap anak. Bisa dikatakan faktor utama dari guru karena guru apalagi untuk guru anak usia pra sekolah, harus memiliki ilmu yang lebih luas.yaitu harus lebih bisa kreatif dalam menciptakan pembelajaran atau permainan yang mana hasilnya bisa mewujudkan/mengembangkan aspekaspek perkembangan anak, mencari cara atau strategi pembelajaran yang dapat menggerakkan anak bisa mengendalikan perasaan, agar terjadi pembiasaan baik. Berdasarkan permasalahan di atas, kami sebagai peneliti, menemukan dan mengambil permasalahan ini karena hampir rata-rata sikap anakbelum berkembang dilihat dari empatinya, permasalahan tersebut, yaitu permasalahan pada anak maupun permasalahan pada guru di TK tersebut, yaitu kurangnya atau belum memahaminya cara pembelajaran yang bisa meningkatkan atau menstimulus tertanamnya sikap empati pada anak. Dan jarangnya penerapan metode mendongeng pada anak tersebut, melihat semua itu peneliti mencoba mengambil judul "Meningkatkan Sikap Empati Pada Aanak Usia Dini Melalui Metode Mendongeng". Peneliti mengharapkan dengan metode mendongeng ini dapat membantu meningkatkan sikap empati pada anak dan bisa memberikan suatu kiat pada guru di lembaga TK Bustanul Arifin dalam membangun sikap anak.

Dari semua nya tersebut dapat dianalisis belum berkembang dari sikap empati anak, guru belum memahami strategi atau cara penerapan pembelajaran yang 
bisa menstimulus anak dalam meningkatkan sikap empati. Melihat semua itu peneliti mengambil batasan masalah bahwa pengembangan Empati "masih belum berkembang". Sesuai dengan permasalahan, maka rumusan masalahnyayaitu: "Bagaimanakah meningkatkan pengembangan empati anak melalui metode mendongeng di TK Bustanul Arifin?

\section{Pengertian Empati}

EmpatiyaituKemampuan untuk mengetahui perasaan orang lain. Wiwi Rosmawati, (2013: 34). Sedangkan pengertian Empati dalam buku yang dicetak oleh Ali Nugraha dan Yeni Rachmawati, (2007: 9.8-9.10) Empati yaitu kemampuan untuk menempatkan diri pada posisi orang lain, mengerti pandangan dan perasaan orang tersebut atau untuk mengalami seperti apa yang dirasakan atau dialami orang tersebut.

Hal ini membutuhkan suatu kesadaran. tidak seperti kecerdasan dan daya tarik fisik, yang sangat tergantung pada genetika. Empati yaitu keterampilan yang anak-anak pelajari, nilainya adalah mutipeld. Anak-anak yang empati senantiasa untuk berbuat lebih baik, dalam situasi sosial dan dalam karir mereka dewasa.Empati dipandang sebagai pemimpin rekan-rekan mereka, para guru terbaik keterampilan dan orang tua nak-anak.

\section{Pengertian Dongeng}

Dongeng terbagi menjadikedalam tujuh bagian, yaitu mitos, sage, fabel, legenda, cerita lucu, cerita pelipur lara, dan perumpamaan. Jenis-jenis dongeng antara lain:

Mitos: isi dongeng yang menceritakan hal-hal magis seperti cerita tentang dewadewa, peri atau Tuhan;

Sage: dongeng kepahlawan, keberanian.

Fabel: dongeng mengenai binatang .

Legenda:ialah sebuah peristiwa asal usul tempat.

Cerita jenaka: cerita yang berkembang dimasyarakat dan dapat mengundangtawa;
Cerita pelipur lara: biasanya bebentuk narasi yang bertujuan untuk menghibur tamu dipesta dan kisah yang diceritakan oleh seorang ahli; dan Cerita tersebut ada didaerah dan dinamakan cerita lokal (Dudung, 2015).

Berbagai jenis dongeng tersebut memiliki fungsiyang dapat dimanfaatkan sebagai sumber pengembangan empati. Hanya saja, pendidik perlu memilihkan dongeng yang bagus serta menambah minat anak. Metode Mendongeng

Menurut Prof. Dr. Muchlas Samani (2013: 30) metode mendongeng pada hakikatnya sama dengan metode ceramah yaitu metodesecara lisan artinya guru menyampaikan materi ajarnya dengan menuturkan secara lisan. Tetapi dalam metode mendongeng guru lebih leluasa berimprovisasi. Untuk itu apabila kita mau menggunakan dongeng sebagai metode pengajaran pada anak hendaknya kita memahami unsur-unsur penting. unsur tersebut antara lain:

Unsur Visual

Unsur ini berkaitan dengan benda-benda yang akan dijadikan alat bantu mentranspormasi pesan dalam mendongeng.

Unsur Aural

Unsur aural pada dongeng yaitu melatih kemampuan anak dalam mendengar dengan memiliki kemampuan, diharapkan anak mampu dan terbiasa mendengar informasi secara imajinatif sehingga kemampuan visualisasinya semakin meningkat.

Unsur Kinestetik

Unsur ini yaitu keluwesan gerak tubuh guru atau pendongeng saat mengajar dengan tekhnik mendongeng.

Unsur Tema.

Unsur tema adalah Graned Design dari dongeng secara keseluruhan tema menjadi kunci dan tujuan dalam membangun membentuk serta mengarahkan cara pandang peserta didik menuju cara pandang positip.Pendidik harus mempersiapkan dongeng yang sesuai dengan materi yang akan 
disampaikan. Unsur Tokoh dan Watak. Unsur ini berfungsi untuk membentuk karakter anak . Unsur Kesan, menurut Dr. Bambang Q Anees (2013: 42) tindakkan selalu merujuk pada sesuatu yang berkesan dongeng merupakan kumpulan pesan dan kesan yang secara alami dan tanpa sadar melekat dihati siapapun pendengar dongeng.

\section{Metode Penelitian}

Terjadi peningkatan kemampuan empati yang ditunjukkan anak dalam kegiatan bermain atau pembelajaransesudah diterapkannya metode metode penelitian yang digunakan adalah cara penelitian tindakan Menurut Taggart (2014: 40) yaitu pada prosedur pelaksanaan PTK mencakup:

1. Penetapan pokus masalah penelitian.

2. Perencanaan tindakan.

3. Pelaksanaan tindakan.

4. Pengamatan interpretasi.

5. Refleksi.

Awal dilaksanakanyaitu tanggal 8 Maretsampaidengan 26 April 2018. Peneliti melakukan Penelitian tindakandengan harapan untuk mendapatkan gambaran.untuk meningkatkan sikap empati anak pra sekolah, yang dilaksanakan melalui 4 tahap yaitu: tahap perencanaan, pelaksanaan, dan refleksi. Parsitipan ini terdiri dari: peneliti, guru kelas, dan anak-anak kelompok A di TK Bustanul Arifin sebagai subjek penelitian dengan jumlah 25 anak terdiri dari 13 anak perempuan dan 12 anak laki-laki.

Tekhnik pengumpulan datadalam penelitian ini adalah pengamatan dan dokumentasi. Menurut Creswell, (2014: 261) instrumen dalam penelitian ini adalah dengan mengumpulkan sendiri data dengan dokumentasi dan observasi perilaku.

\section{HASIL PENELITIAN DAN PEMBAHASAN}

Setelah kami melaksanakan penelitian, mengenai Kemampuan empati anak, sebelum diterapkan metode mendongeng, terlihat sikap anak rendah. Hal ini di dapat dari hasil wawancara awal yang dilakukan peneliti dengan guru kelas, serta observasi awal yang dilakukan terhadap anak.Menyiapkan alat yang akan dipakai untuk mendongeng, meneliti aspek-aspek kemampuan empati yang akan diobservasi yaitu toleransi, mengasihi, dan membantu teman serta meneliti indikator setiap aspek yang akan diobservasi oleh peneliti kemudian menyiapkan media yang akan digunakan. Pemahaman empatidilihat cukup meningkat sesuddah diterapkan metode mendongeng, semua terlihat dari hasil pengamatanberupa catatan lapangan dan hasil wawancara guru, pada kenyataannya sikap anak mulai berubah dilihat dari pemahaman dalam kemampuan empati. Selama proses mendongeng mengalami peningkatan setiap aspeknya maupunindikatornya.

Selama proses tindakan peneliti menelaah telah terjadi peningkatan kemampuan empati yang ditunjukkan anak dalam kegiatan pembelajaran atau kegiatan bermain. Pada pra siklus kemampuan empati anak-anak masih belum berkembang yaitu 15 orang anak, kategori mulai berkembang 7 orang anak, kategori yang berkembang sesuai harapan 3 orang anak dan untuk kategori berkembang sangat baik tidak ada.

Penerapan metode mendongeng pada siklus satu meningkat jadi 10. Kategori belum berkembang, kategori mulai berkembang 11 orang anak, kategori berkembang sesuai harapan 4 anak orang. Untuk berkembang sangat baik belum terlihat. Kemudian dilakukan refleksi yaitu perbaikanpelaksanaan tindakan pada siklus kedua kemampuan empati anak mengalami peningkatan yang cukup baik tapi masih ada tiga orang anak pada kategori belum berkembang karena kedua anak tersebut membutuhkan bimbingan khusus dari guru saat melakukan kemampuan empati. Kategori belum berkembang semakin menurun ada 
3 orang anak, kategori mulai berkembang menjadi 7 orang anak, dan kategori sesuai harapan menjadi 1 lorang anak dan kategori berkembang sangat baik terlihat muncul ada 4 orang anak. Dengan dilakukannya metode mendongeng, dapat dilihat cukup epektif pada peningkatan kemampuan empati anak. terlihat dari hubungan dengan teman, antri menunggu giliran ketika bermain, tidak marah pada teman.

Menurut Teori yang dicetak oleh Wiwi rosmawati, (2013: 34) empati berarti sikap toleran. dalam konteks anak, empati orang tua tercermin dari bagaimana orang tua dapat memahami apa yang dirasakan anak.

Empati ialahsikap seseorang karena sangat berpengaruh bagi kehidupan anak ataupun bersosialisasi baik itu dilingkungan keluarga, sekolah, maupun dilingkungan masyarakat. Penerapan melalui metode mendongeng dengan alat, seperti boneka tangan, boneka jari, bukubuku cerita, dan lain-lain. Memiliki bannyak kelebihanyaitu, anak lebih antusias dalam mendengarkan cerita, fokus dan konsentrasi, sehingga anak tidak merasa bosan.

\section{KESIMPULAN}

Masih rendahnya empati anaksebelum dilakukan tindakan. Penyebabnya ialahfungsi pendidik yaitu kurangnya memahami atau menguasai cara, strategi pembelajaran. dalam arti guru kurang kreatif yaitu selalu monoton dalam memberikan pembelajaran.jadi dibutuhkan strategi yang lebih epektif untuk peningkatan sikap tersebut, yaitu dengan menggunakan metode mendongeng.

Kemampuan empati anak kelompok A di TK Bustanul Arifin, sesudah dilakukan penerapan metode mendongeng, mengalami peningkatan yang bertahap pada setiap siklusnya.

Guru diharapkan dapat secara konsisten menerapkan metode mendongeng, Sekolah hendaklah menyediakan berbagai media untuk mendongeng disemua kelas.

Peneliti diharapkan dapat melakukan penelitian secara lebih mendalam dan mencari metode lain yang bisa lebih menstimulus perkembangan empati anak.

\section{DAFTAR PUSTAKA}

Nugraha Ali \& Yeni Rahmawati (2007). Metode Pengembangan Sosial Emosional.

Jakarta: Universitas Terbuka

Rosmawati Wiwi. (2013). Pembentukan Karakter Dimulai Sejak Usia Dini.

Bandung: CV OMAHIMA

\section{http://jurnal.untan.ac.id/index.php/jpdpb/ article/view/13035, diakses 1 April 2018}

